\title{
Hyperbaric Oxygen (HBO) Reduce Expression of Hypoxia- Inducible Factor-1 Alpha (HIF-1 alpha) and Endometriotic Tissue Size in Mice Model of Endometriosis
}

\author{
Dedy Syahrizal ${ }^{1 *}$, Cut Mustika ${ }^{2}$, Teuku Renaldi ${ }^{2}$, Mohammad G. Suryokusumo ${ }^{3}$, and Hendy Hendarto ${ }^{4}$ \\ ${ }^{1}$ Department of Biochemistry, Medical Faculty, Universitas Syiah Kuala, Banda Aceh, Indonesia \\ 2 Department of Public Health, Medical Faculty, Universitas Syiah Kuala, Banda Aceh, Indonesia \\ ${ }^{3}$ Medical Hyperbaric Study Program, Faculty of Medicine, Universitas Airlangga, Surabaya, Indonesia \\ ${ }^{4}$ Department of Obstetrics and Gynaecology, Faculty of Medicine, Universitas Airlangga, Surabaya, Indonesia
}

\begin{abstract}
Hypoxia in endometriosis will increase the expression of Hypoxia Inducible Factor-1alpha (HIF1alpha) and its expression could be decreased by Hyperbaric Oxygen (HBO). This study aimed to analyze the effect of HBO 2.4 ATA for 3x30 minutes per day for 10 days on the expression of HIF-1 alpha and endometriotic tissue size on mice model of endometriosis. This study was an experimental laboratory study with a separate pretest-posttest control group design. The mice were divided into three groups, the first was a pretest control group (which describes the condition after endometrium transplantation), the second was the endometriotic group that received hyperbaric oxygen, and the third was the endometriotic group that did not receive hyperbaric oxygen therapy. The endometriosis implant size in the peritoneal tissue was assessed and the immunohistochemistry examination was conducted to determine the expression of HIF-1 alpha. The endometriosis tissue size was reduced in the HBO group compared to the control and nonHBO group. The lowest expression of HIF-1 alpha was significantly found in HBO over the other group. The decrease of HIF1 alpha expression mediates the reduction of size endometriotic tissue due to the therapy of HBO.
\end{abstract}

Keywords: hypoxia, endometriosis, hyperbaric oxygen (HBO), hypoxia-inducible Factor-1 alpha (HIF-1 $\alpha$ ).

\section{Introduction}

Hypoxic conditions occur in endometriosis. The hypoxic conditions are due to the dysregulation of immune cells and cytokines released by endometriotic tissue[1,2]. Hypoxic conditions are known to cause an increase in the expression of Hypoxia-Inducible Factor-1 alpha (HIF-1 alpha), this situation is also found in endometriosis tissue $[3,4]$. According to the previous study, HIF-1 alpha plays a role in increasing the expression of estrogen receptor $\beta$ which triggers the endometriosis[5]. This increase then leads to the expression of vascular endothelial growth factor (VEGF), which is required by endometriosis tissue to carry out angiogenesis so that the network can continuously evolve [6,7]. Based on this process, an attempt to decrease the expression of HIF-1 alpha is predicted to be a potential approach to treat endometriosis.

Hyperbaric oxygen (HBO) is a therapy that uses a pressurized chamber to increase the amount of oxygen in the blood. According to several studies, HBO may decrease the expression of HIF-1 alpha because the oxygen-rich atmosphere would increase the breakdown of HIF-1 alpha protein by the ubiquitin system. ${ }^{[8]}$ Concerning endometriosis, $\mathrm{HBO}$ is predicted to decrease the expression of HIF-1 alpha in the endometriosis tissue.

\section{Materials and methods}

This study has been ethically approved by the Animal Care and Use Committee (ACUC) Faculty of Veterinary Medicine, Universitas Airlangga (Approvement No. 497$\mathrm{KE})$.

\subsection{Animals}

Twenty-eight female mice of three-month-old were randomly divided into three groups:

Group 1: pretest control group which was examined immediately after endometriosis implantation,

Group 2: an endometriotic group that received hyperbaric oxygen for ten days,

Group 3: an endometriotic group that did not receive hyperbaric oxygen therapy.

\subsection{Endometriosis modeling}

Mice have given intramuscular cyclosporin A injection at the dose of 10 milligrams per kilogram of body weight on the first day to make the mice immune-deficiency. Furthermore, endometrial tissue formula was injected into the mice intraperitoneally. The endometrial tissue was taken from myometrium and adenometrium of adenomyosis patients. The tissue is then stored in

* Corresponding author: dedysyahrizal @unsyiah.ac.id 
phosphate buffer saline (PBS). The tissue was washed two times with a centrifuge at a speed of $2500 \mathrm{rpm}$. The supernatant was discarded then PBS, penicillin $200 \mathrm{IU} / \mathrm{ml}$ and streptomycin $200 \mathrm{mg} / \mathrm{ml}$ were added. Each mouse received $0.1 \mathrm{ml}$ injection of the formula. Following the endometriosis tissue formula injection, the mouse received intramuscular estrogen injection in the thigh at a dose of 30 milligrams per kilogram of body weight on the first and fifth day after the endometriosis tissue formula injection. On the fourteenth day, all the mice have become models of endometriosis. ${ }^{[9,10]}$

\subsection{Hyperbaric oxygen (HBO)}

Mice of Group 2 were placed in a hyperbaric chamber a day after they became models of endometriosis. The procedure was conducted by using 2.4 ATA hyperbaric oxygen for three 30-minute periods with a five-minute air break between periods. The procedure used $100 \%$ of oxygen at a flow rate of $8-10 \mathrm{l} / \mathrm{min}$. The hyperbaric oxygen procedure was conducted once a day for ten days. $^{[8]}$

\subsection{Histopathology examination}

Laparotomy was performed to collect the mice's endometriosis tissue. The tissue was then placed on a plate containing phosphate-buffered saline (PBS), fixed and dehydrated in acetone at a temperature of $-20^{\circ} \mathrm{C}$ for 20 hours. The tissue was purified with methyl benzoate and xylene and was impregnated with paraffin. The paraffin block was then stored at a temperature of $4^{\circ} \mathrm{C}$. Each of the blocks was sliced into $100 \mu \mathrm{m}$-thick slices. ${ }^{[11]}$

\subsection{Determination of HIF-1 alpha expression}

The determination of HIF-1 Alpha was conducted with immunohistochemistry staining by using an anti-HIF-1 alpha antibody from Abcam (ab16066). The examination procedure of HIF-1 Alpha expression was conducted by the standard listed on the kit. HIF-1 alpha expression was measured semiquantitatively with the modified Remmele method, where Immuno Reactive Score (IRS) was the result of multiplication between immunoreactive cell percentage score and immunoreactive cell color intensity. Datum of each sample was the IRS score observed on five different viewing fields with 1000-times magnification. ${ }^{[12]}$

\subsection{Measurement of endometriosis tissue size}

Measurement of endometriosis tissue size was conducted by using Image Ruster 2 software with 1-mm precision.

\subsection{Data analysis}

Data are presented as mean \pm standard deviation and the differences between groups were analyzed by using the ANOVA test followed by LSD as a post hock test.

\section{Results and Discussion}

\subsection{Results}

\subsubsection{HIF-1 alpha expression}

The lowest HIF-1 alpha expression was found on the mice group that received hyperbaric oxygen. Visual description of the HIF-1 alpha expression is described in Figure 1.
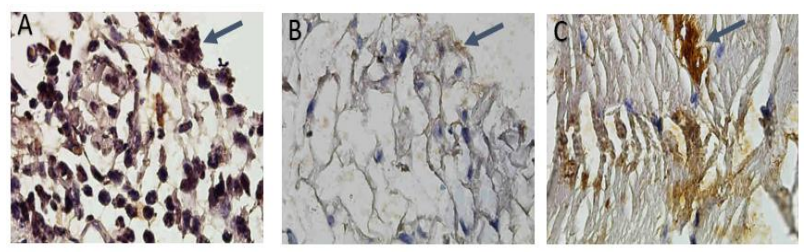

Figure 1. Comparison of inflammatory area HIF-1 alpha expression among treatments. Positive immunoreactive cells are shown by inflammatory cells, endothelial cells, and fibroblasts (arrows). It is evident in this study that HIF expression (chromogen brown color) of the group that received hyperbaric oxygen therapy (B) is much lower than that of the pretest control group (A) and the group that did not received hyperbaric oxygen therapy (C) (Immunohistochemistry staining, 1000 times magnification; Nikon H600L microscope; 300 megapixels DS Fi2 camera).

A significant HIF-1 alpha expression difference was found between the three groups $(p=0.000)$. The difference was found between Group 1 and Group $2(\mathrm{p}=0.000)$ and between Group 2 and Group $3(\mathrm{p}=0.036)$. The HIF-1 alpha expression comparison between Groups is described in the following table and graph.

Table 1. Expression HIF-1 alpha comparison between group

\begin{tabular}{ccc} 
Group & HIF-1 alpha expression & $p$ \\
\hline 1 & $8,25 \pm 1,25$ & \\
2 & $1,60 \pm 1,43$ & 0,000 \\
3 & $3,42 \pm 0,98$ &
\end{tabular}

\subsubsection{Endometriosis tissue size}

All mice on all groups were healthy on the day after the modeling process is completed. Surgery was conducted on mice in Group 1 on the day after the modeling process is completed. All mice in Group 1 developed endometriosis with the appearance of plaque and hyper vascularization. The result suggested that the endometriosis modeling process was carried out successfully and other groups could proceed with the study.

Surgery was conducted on mice in Group 2 and 3 on the eleventh day after the surgery on Group 1. Endometriosis tissue size of Group 2 was found smaller than that of Group 1 and 3 as seen in figure 1 . 

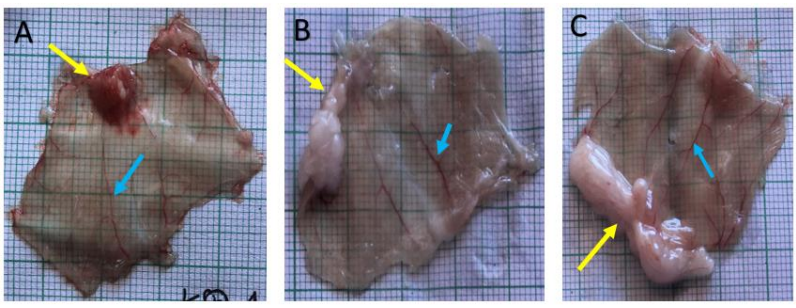

Figure 2. Peritoneun of endometriosis mice. Endometriosis lesions were found in the form of plaque growth (yellow arrows) and hypervascularization (blue arrows). There was a decrease in the area of endometriosis lesions in the group given HBO (B) compared to the pretest control group (A) and the group that did not receive hyperbaric oxygen $(\mathrm{C})$ therapy.

A significant endometriosis tissue size difference was found among the three groups $(p=0.002)$. the difference was found between Group 1 and Group $2(\mathrm{p}=$ 0.013 ) and between Group 2 and Group $3(p=0.027)$. The endometriosis tissue size comparison between Groups is described in the following table and graph.

Table 2. Endometriosis tissue size comparison between groups.

\begin{tabular}{ccc}
\hline Group & $\begin{array}{c}\text { Endometriosis Tissue Size } \\
\left(\mathrm{mm}^{2}\right)\end{array}$ & $p$ \\
\hline 1 & $207,09 \pm 91,25$ & \\
2 & $49,36 \pm 48,94$ & 0,002 \\
3 & $209,53 \pm 190,44$ & \\
\hline
\end{tabular}

A significant difference was found between mice with $\mathrm{HBO}$ and those without HBO. Endometriosis tissue size on Group 2 was nearly ten times smaller than that of Group 1 and was five times smaller than that of Group 3.

\subsection{Discussion}

The pretest control group (Group 1) is the Group that was designed to identify the endometriosis tissue before HBO therapy. HIF-1 alpha expression was found highest in this group. This finding indicates that endometriosis develops in hypoxic conditions. This condition was predicted to induce a series of regulations that would allow the endometriosis tissue to continue its development.

Expression of HIF-1 alpha on the group that received HBO therapy on 30-minutes 2.4 ATA dose 3 times daily for 10 days was found significantly lower. This finding indicates that HBO therapy on 30-minutes 2.4 ATA dose 3 times daily for 10 days increases cellular oxygenation which corrects the tissue hypoxic condition. The increase in oxygen level automatically develops normoxic - or even hyperoxic - condition. Under the normoxic and hyperoxic conditions, HIF-1 will be hydroxylated on specific prolyl residual due to prolyl hydroxylase (PHD) enzyme activation. Under this condition, von Hippel Lindau protein (pVHL) will form a complex that will activate E3 ubiquitin ligation that will form ubiquitinylate HIF-1 alpha; this process degrades the HIF-1 alpha. ${ }^{[8]}$

The mice group that did not receive HBO therapy (Group 3) was treated in a chamber filled with free air without extra pressure. HIF-1 alpha expression on this group was found lower than that of the pretest control group; however, it was higher than that of Group 2. The possible cause of this finding was the endometriosis tissue development that had to reach its optimum level in 14 days after modeling (maturation stage). As it has been known, the endometriosis tissue did not spontaneously develop in the modeled mice; instead, the development was stimulated by implantation followed by hormonal and immunosuppressant administration. When the modeling process was estimated to be complete on the fourteenth day, Group 3 no longer had the triggering factor needed for the development of endometriosis tissue. This situation caused the absence of a growth signal which leads to HIF-1 alpha not be expressed. This finding confirms the result of a previous study that found a lower NFk $\beta$ expression on the HBO therapy group compared with the control group. The decrease of $\mathrm{NFk} \beta$ expression is estimated to cause the absence of growth signal which leads to the decrease of HIF-1 alpha expression. This happens because HIF-1 alpha regulation is strongly influenced by $\mathrm{NFk} \beta$ activity. ${ }^{[13]}$

The presence of HIF-1 alpha is estimated to influence the increase of endometriosis tissue size. This is proved by the decrease of endometriosis tissue size due to the decrease of HIF-1 alpha expression. This is because HIF-1 alpha has an important role in various mechanisms that form the endometriosis tissue. The decrease of HIF-1 alpha expression will activate DUSP-2 which inhibits ERK phosphorylation; this will prevent the formation of the COX-2 enzyme which would be necessary for the formation of prostaglandin E2 (PGE2). ${ }^{[14,15]}$ As a result, the modulation of endometriosis tissue development processes such as steroidogenesis, cell proliferation, angiogenesis, and immune cell suppression does not occur. Moreover, the low PGE2 level will prevent the feedback loop effect on HIF-1 alpha. ${ }^{[2]}$

According to the discussion above, it can be deduced that HBO has an important role in decreasing or in increasing the HIF-1 alpha expression. HBO dose of 30-minutes 2.4 ATA 3 times daily for 10 days was significantly effective in decreasing HIF-1 alpha expression on endometriosis tissue of model mice. The decrease of HIF-1 alpha expression is a strategic condition in the management of endometriosis. This confirms several previous studies that found that HIF-1 alpha was subcellular protein necessary for cell proliferation on endometriosis tissue.

\section{Conclusion}

Hyperbaric Oxygen (HBO) dose of 30-minutes 2.4 ATA 3 times daily for 10 days can decrease endometriosis tissue size by decreasing HIF-1 alpha expression.

\section{Acknowledgments}

The authors would like to thank Balai Penelitian dan Pengembangan Kesehatan (BALITBANGKES) Departemen Kesehatan RI for financial support and Lembaga Kesehatan Kelautan (LAKESLA) RSAL 
Ramelan Surabaya for the opportunity to use the animal hyperbaric chamber. The authors would also like to thank Mrs. Widjiati, DVM, M.Sc, PhD, Mr. Djoko Legowo DVM, M.Sc and team for the technical support on this study.

\section{References}

1. Tariverdian N, Theoharides TC, Siedentopf $\mathrm{F}$, et al.: Neuroendocrine- Immune Disequilibrium and Endometriosis: an Interdisciplinary Approach. Semin Immunopathol. 2007; 29: 193-210.

2. Hsiao KY, Lin SC,Wu MH, Tsai SJ: Pathological functions of hypoxia in endometriosis. Frontiers in Bioscience, Elite. 2015; 7 : 352-366.

3. Ren X, He YL, Pan SL et al. :Expression of hypoxiainducible factor-1alpha in endometriosis. Nan Fang $\mathrm{Yi}$ Ке Da Хие Хие Ваo. 2007; 27(4):538-540.

4. Wu MH, Chen KF, Lin SC, et al. : Aberrant expression of leptin in human endometriotic stromal cells is induced by elevated levels of hypoxia inducible factor-1 alpha. Am J Pathol. 2007; 170(2): 590-598.

5. $\mathrm{Wu} \mathrm{MH}, \mathrm{Lu} \mathrm{CW}$, Chang FM, et al. : Estrogen receptor expression affected by hypoxia inducible factor-1 $\alpha$ in stromal cells from patients with endometriosis. Taiwan J Obstet Gynecol. 2012; 51(1): 50-54.

6. Goteri G, Lucarini G, Zizzi A, et al.: Proangiogenetic molecules, hypoxia-inducible factor-1alpha and nitric oxide synthase isoforms in ovarian endometriotic cysts. Virchows Arch. 2010; 456(6):703-710.

7. Imesch P, Samartzis EP, Schneider M, et al. : Inhibition of transcription, expression, and secretion of the vascular epithelial growth factor in human epithelial endometriotic cells by romidepsin. Fertil Steril. 2011; 95(5):1579-1583.

8. Mulawarmanti D : Profil cAMP, NFkB, iNOS, dan MMP3 Jaringan Periodontal Tikus Winstar Pada Kondisi Hiperglikemia yang Terpapar Hiperoksia Hiperbarik. Dissertation. Program Pasca Sarjana Universitas Airlangga Surabaya. 2008.
9. Vika SP, Hendarto H, Suhartono DS, et al. : Pengaruh Pemberian Siklosporin A Sebagai Penurun Jumlah Limfosit serum Terhadap Terjadinya Implan Endometriosis Pada Mencit. Available in Pengaruh Suplementasi Kurkumin Terhadap Maturasit Oosit dan Viabilitas Embrio Hasil Fertilisasi In Vitro Pada Mencit Model Endometriosis. Laporan Penelitian Unggulan Strategis Nasional. 2010; 18.

10. Hendarto H, Widjiati, Sudiana IK, et al. : Khasiat kurkumin terhadap Perubahan ekspresi VEGF, GDF9, Hyaluronan untuk Perbaikan Terapi dan Hasil Fertilisasi Pada Endometriosis. Laporan Penelitian Unggulan Strategis Nasional. 2009; 17.

11. Sudiana IK: Teknologi Ilmu Jaringan dan Imunohistokimia Ed.1. Sagung Seto. 2005; 1-51.

12. Novak M, Madej JA, Dziegeil P: Intensity of Cox 2 expression in Cell of Soft Tissue Fibrosarcomas in Dog As Related to Grade of Tumor malignation. Bull Vet inst Pulawy. 2007; 51: 275-279.

13. Jung YJ, Isaacs JS, Lee S, et al. : IL-1beta-mediated upregulation of HIF-1alpha via an NFkappaB/COX-2 pathway identifies HIF-1 as a critical link between inflammation and oncogenesis. FASEB $J$. 2003 ;17(14):2115-2117.

14. Kaidi A, Qualtrough D, Williams AC, et al.: Direct Transcriptional Up-regulation of Cyclooxygenase-2 by Hypoxia-Inducible Factor (HIF)-1 Promotes Colorectal Tumor Cell Survival and Enhances HIF-1 Transcriptional Activity during Hypoxia. Cancer Res. 2006 ; 66 (13): 6683-6692.

15. Wu MH, Lin SC, Hsiao KY: Hypoxia-inhibited dualspecificity phosphatase-2 expression in endometriotic cells regulates cyclooxygenase-2 expression. $J$ Pathol. 2011; 225(3):390-400. 